\title{
Journal of Public and Nonprofit Affairs
}

\author{
Vol. 7, No. 3
}

\section{Practice and Theory: The Diffusion of State Legislative Budget Reform}

\author{
Sungkyu Jang - Indiana University-South Bend \\ Sung-Jin Park - Indiana University-South Bend \\ Robert J. Eger III - University of the Pacific
}

\begin{abstract}
We question why some state legislatures responded to public discourse promptly while other state legislatures resist change. We use the choice of performance-based budgeting $(\mathrm{PBB})$ to set the stage in answering this compelling question. We employ a logit model as a discrete event history analysis (EHA). We use the EHA to determine how and what variables influence the probability of an organization's qualitative change (or "event") at a given point in time. In this study, the organizations are states, and the event to be analyzed is the enactment of PBB law. Our data set is a modified panel of 50 states between the years 1993 and 2008. We study the factors that would influence state legislators to pass PBB laws across the nation. While our empirical result shows that political preferences are not statistically significant factors for states to pass PBB law, state legislators seem to favor the factors associated with the financial management explanation to adopt PBB. Also, the factors of path dependence and mimicking influence states to adopt PBB.
\end{abstract}

Keywords: Performance-Based Budgeting, Event History Analysis, Budgetary Rule Choice

The intellectual foundation of performance-based, mission-driven, and result-oriented government reform initiatives, commonly known as 'new public management' (NPM), was ushered into the public discourse in the United States in the early 1990s. In essence, the spirit of NPM reform requires the shift in focus from procedural accountability to managerial discretion in the use of public resources. As Thompson (1994) noted, NPM reform demands changes in the legislative budgetary process delegating budget authorities to the entities responsible for the delivery of government results.

Despite the pervasive reform effort, implementation strategies of the NPM reform were not uniform. While some state legislatures followed a strategy similar to the federal government, enacting performance-based budget laws, other state legislatures simply relied on the executive budget process to infuse more performance information into public resource allocation. Lu et al. (2011) provided compelling evidence suggesting that comprehensive performance-based budgeting (PBB) laws lead to more effective implementation. Given this positive relationship, the question of why some state legislatures responded to the public discourse in a timely manner while other state legislatures resisted the change is compelling. Indeed, timely responders such as Texas, Florida, and Minnesota, to name a few, are considered as the states with more effective PBB systems (Grizzle \& Pettijohn, 2002; Melkers \& Willoughby, 1998).

Jang, S., Park, S.-J., \& Eger III, R. J. (2021). Practice and theory: The diffusion of state legislative budget reform. Journal of Public and Nonprofit Affairs, 7(3), 307-323. https://doi.org/10.20899/jpna.7.3.307-323 
Within the public administration literature, significant attention has been given to understanding why state governments choose a certain form of the budgetary process. From the previous literature on policy adoption and diffusion, we drew upon the work of four different (but not mutually exclusive) accounts of budgetary rule choice: fiscal management demand, political preference, path dependence to the existing fiscal institutions, and budget mimicking hypotheses. Although the legislative involvement is considered as a critical success factor of performance-based budget reform (Bourdeaux, 2006), the legislators' motivating factors for PBB law enactment have been ignored by prior studies.

Several prior studies on PBB tried to explain why a state would choose to adopt or not adopt the performance-based budget using an interview on perceptions of budget officials and state lawmakers (Hou et al., 2011; Melkers \& Willoughby, 2001). However, the different explanations on budget reviewers' motivations to enact PBB have not been tested based on empirical data. This study intends to fill this void by examining the temporal pattern of states' enactment of performance-based budget laws. Using four different explanations of budgetary rule choice and event history analysis (EHA), we investigated those legislative adoption decisions and identified the four groups of key factors that would lead some state legislatures to earlier adoption of PBB laws.

We address timeliness in PBB adoption using an event history approach. Our results provide empirical support for the diffusion of federal budgetary reform through the state legislatures' enactment of PBB laws. Our findings are in line with the view that the adoption of PBB can be explained by practicing state legislators' eclectic consideration of the usefulness of PBB adoption for strategic fiscal management, political preference, path dependence, and the tendency of budget mimicking behavior, as offered by the academic literature. State legislators seem to favor the factors associated with the financial management explanation, however that too is limited on impact of adopting PBB. Rather, important factors of the four different theoretical explanations appear to be considered by state legislators.

The remainder of this paper is organized as follows: In the first section, we discuss the background of legislative involvement in the PBB in both the federal and state governments during the 1990s. Next, a framework of budgetary rule choice is established using four different explanations. In the third section, we describe the event history analysis (EHA) model used, data, and methodology. The final two sections include the analyses and discussion of the results and draw upon the analyses to provide conclusions about PBB implementation.

\section{Legislating Performance-Based Budgeting}

Since the first Hoover Commission's emphasis on the managerial orientation of the budgetary process in the late 1940s, the idea of PBB has been explored by the federal government (Schick, 1966). In parallel, state governments (for example, California and Utah) formed their own version of 'little Hoover Commissions' and instituted PBB systems focusing on their executive budget process. The majority of states claimed to embed performance information in the governors' budget proposals. Their efforts to infuse performance information into the executive budget proposal were mainly based on the governors' executive orders or state agencies' voluntarily developed budget-making practice. However, there was a lack of legislative effort to the enactment of PBB in order to require governors and state agencies to link performance measures to the budgetary process, including not only making executive budget proposals but also legislative budget review using performance information. As Schick (1971) pointed out, this lack of legislatures' commitment to link performance measures to budgetary process is partly due to the legislatures' reluctance to curtail line item-based budget control. It was quite difficult to overcome the long-standing tradition of the input-based budgetary process. 
In the history of budgetary reform initiatives in the United States, Joyce (1993a) indicated that there is a tendency of revisiting the same reform ideas such as PBB. At the federal level, the reform initiative toward "rational" budgeting resurfaced in the early 1990s through the enactment of a series of laws providing an institutional foundation for PBB. First, the Chief Financial Officers Act of 1990 required the establishment of cost accounting systems and audited financial statements by the federal government. Subsequently, the Government Performance and Results Act (GPRA) of 1993 was enacted to stipulate the overall structure of a government-wide performance-based management system (Breul, 2007). While the previous effort to implement PBB had failed due to inadequate participation of budgetary actors (i.e., legislators), the GPRA of 1993 epitomized the legislatures' commitment to linking their budget review with the agency's strategic planning and performance measurement effort.

At the federal level, the GPRA of 1993 is characterized as requirements for strategic planning with focusing on results rather than activities (Government Accountability Office [GAO], 1997), annual performance plans and reports (Willoughby \& Benson, 2011), and use of performance measures for justifying agencies' budgets (Jones \& McCaffery, 2010). At the state level, PBB laws encompass the following two main components: (1) link strategic plan, performance measures, and budget, and (2) include oversight, incentives, and evaluation of performance measures. This study defines PBB as a budget reform to link performance measures and budget decisions. While the term 'performance budgeting' or 'performanceinformed budgeting' is recently more often used to define this reform more broadly, we use the term 'performance-based budgeting' to highlight the initial idea of this budget reform. The narrow but original thought of this budget reform concentrated on the shift of focus from inputs or activities (input-based) toward results (performance-based). Also, PBB focuses on the use of performance measures for the funding decision (performance-based funding decision) rather than traditional need-based funding decision.

At the state level, a similar legislative effort was gaining momentum following GPRA of 1993 . While there are some variations in the timing of enacting PBB laws across states, Table 1 shows that the majority of states (36 of 50 states) had enacted PBB from 1993 to 2009 (Lu et al., 2009). We argue that legislators' enactment of PBB law itself is a stronger change in budgetary rule than executive level practice without PBB enactment. Table 1 shows the years that states enacted PBB laws after the enactment of GPRA.

\section{Explanations of Budgetary Rule Choice}

The multiple roles to be served by PBB would induce different levels of the demand for PBB across states based on each state government's political, managerial, and economic conditions. As such, while all states were exposed to the exogenous shock of GPRA of 1993, the timing of enacting PBB laws would be endogenously determined by states. In order to understand the factors behind the timeliness of enactment of PBB laws by states, we draw upon the work of four different accounts of budgetary rule choice: fiscal management, political preference, path dependence, and budget mimicking.

\section{Fiscal Management}

Fiscal management is primarily focused on financial risk in a state. There are four orientations to consider for budgeting: planning, management, control, and funding. Schick (1966) pointed out the multifaceted financial functions of a budget, saying "every budget system, even rudimentary ones, comprises planning, management, and control process" (p. 244). Friedman's (1976) study on municipal budgeting practice added funding as another orientation to Schick's original three typological components. 
Table 1. State Enactments of Performance-Based Budget Laws Following GPRA (Lu et al., 2009)

\begin{tabular}{llc}
\hline \hline Year & \multicolumn{1}{c}{ State } & Number of States \\
\hline & California, Georgia, Idaho, Indiana, Minnesota, Montana, & 11 \\
1993 & Texas, Vermont, Washington, Wisconsin, Wyoming & \\
1994 & Florida, Mississippi & 3 \\
1995 & Alabama, Ohio, South Carolina & 3 \\
1996 & Delaware, Nevada, Rhode Island & 3 \\
1997 & Arizona, Louisiana, Oregon & 1 \\
1998 & Hawaii & 2 \\
1999 & New Mexico, Oklahoma & 1 \\
2000 & Kentucky & 2 \\
2001 & Colorado, Iowa & 2 \\
2002 & Alaska, Tennessee & 2 \\
2003 & Missouri, Nebraska, Utah, Virginia & 4 \\
2004 & Maryland & New Jersey \\
2007 & & 1
\end{tabular}

Note: The following states have not enacted performance-based budget laws since 1993: Arkansas, Connecticut, Illinois, Kansas, Maine, Massachusetts, New Hampshire, New York, North Carolina, North Dakota, Pennsylvania, South Dakota, and West Virginia.

In Stanford's (1992) empirical study on budget deliberations, she examined legislator inquiry about these four components. Stanford (1992) finds that, in planning, legislators are seen to focus on resource allocations; in management, the focus is on "activities of agencies, work measurement, administrative efficiency, and performance" (p. 19), while control is concentrated in "fraud, abuse, and misuse of funds" (p. 19). The final component, funding, conjectures, "Where do we get the money from?" Stanford (1992) showed that the count of state legislators' questions in the budget review process is focused on management (58\%), control (24\%), funding (14\%), and planning (4\%).

Budget reformers traditionally believe that adoption of $\mathrm{PBB}$ is intended to improve budget sponsors' (legislators') rationality in resource allocation (planning). Previous studies on the usefulness of PBB (Aristigueta \& Justice, 2006; Broom \& McGuire, 1995; Hou et al., 2011; Joyce, 1993b, 1997; Lee, 1997; Melkers \& Willoughby, 2001) found little evidence of this traditional belief of PBB in resource allocation. Simply, the budget is not allocated among programs or agencies based on rationality. Empirical results on the impact of PBB on fiscal outcomes (Crain \& O'Roark, 2004; Lee \& Wang, 2009) did not conclude that PBB plays the role of a control device to reduce levels of spending and taxes.

Therefore, we argue that legislators adopt PBB law to address managerial and funding issues in the budget review process. This is distinct from the conventional interpretation of the role of $\mathrm{PBB}$, where $\mathrm{PBB}$ is predisposed to be used as a tool of fiscal management and rational assessment. The argument for the adoption of $\mathrm{PBB}$ as a managerial and funding tool is underpinned in Moynihan (2006), Friedman (1976), and Stanford (1992); Moynihan argued that elected officials adopt PBB to provide a positive impact on organizational effectiveness (managerial), and Friedman and Stanford viewed funding as one of the key functions of a budget. 
To measure the level of managerial demand of legislators, we use the concepts of budget risk and resource dependence. To address budget risk, uncertainty and volatility are key components. The recent literature on state financial volatility contends that volatility should be addressed as a risk (Crain, 2003; Staley, 2015, 2017) related to expected revenue and expenditure streams. The volatility may change the dialogue among participants in the budgetary process. PBB generates information on the unit cost associated with public services provided by each agency. The unit cost information is useful for the government to address an unstable financial environment and unstable revenue structures. As the level of fiscal selfreliance changes, the state is more cost sensitive to maintaining a constant provision of public services. Changing fiscal self-reliance can directly affect the state's need for intergovernmental grants and long-term debt, influencing risk and uncertainty in government finance (Florida Auditor General, 2007). For instance, if a state is highly reliant on federal grants, the state's dependency may require a commitment to follow budgetary rules enforced implicitly and/or explicitly by the federal government. The following hypothesis is derived:

H1: High financial risk, uncertainty, and dependence increase the state's probability of PBB enactment.

\section{Political Preference}

While budget reform has struggled to incorporate rationality into the political process of budgeting (Rubin, 1990), the initiative of budget reform itself may be a political process (Wildavsky, 1961, 1988). As such, the enactment of PBB laws by state legislatures can be a manifestation of the state's political preference toward NPM budget reform following the federal initiatives.

Political preference explanations of budgeting are built on the assumption that the budgetary process is inherently political. The ideological position of the government determines the probability of budgetary rule choice regardless of the financial status of a state. Democratic political ideology is expected to increase spending and taxes (Cameron, 1978; Davis et al., 1974; Kiewiet \& McCubbins, 1985; Tufte, 1978). Correspondingly, we could assume that Republican political ideology is expected to reduce spending and cut taxes. Traditionally, agencies' budgetary behavior has been described as budget-maximizing bureaucrats (Niskanen, 1968, 1971). This opportunistic behavior of agencies is due to their informational advantages (Mitnick, 1975; Smith \& Bertozzi, 1998; Spencer, 1980, 1982). Thus, PBB can be viewed as a device to control the Leviathan-like budgetary behavior of agencies because PBB provides more rich information to budget reviewers (i.e., legislators) in the budgetary process. While results of empirical studies (Crain \& O'Roark, 2004; Hou et al., 2011; Klase \& Dougherty, 2008; Lee \& Wang, 2009; Qi \& Mensach, 2012) on the effects of PBB on spending and revenue are mixed, theoretical argument on the causes and consequences of agencies' budget-maximizing behavior and prescription to mitigate this problem fits the Republican political lens. Therefore, we argue that Republicans' political conservatism is expected to increase the likelihood of adopting PBB to achieve fiscal conservatism not because there is the real effect of the budget form on fiscal health, but because the budget form fits their political preference. The operationalized hypothesis is as follows:

H2: Political conservatism increases the state's probability of PBB enactment.

\section{Path Dependence}

A budgetary reform by the federal government and its diffusion across states does not occur in a vacuum. It is influenced by existing fiscal rules, called path dependence (Pierson, 2000). An individual state's budgetary rule choice can be explained as an endogenous rule choice influenced by the existing arrangements of fiscal institutions. Although we are focusing on the potential vertical diffusion of PBB law enactment following GPRA at the federal level, an 
individual state's prior experience of having old PBB laws may reinforce the state's adoption of a more sophisticated and rigorous version of $\mathrm{PBB}$.

Other fiscal rules emphasizing financial prudence may lead to a greater demand for a PBB system. Many states have fiscal self-control rules, such as a Balanced Budget Rule (BBR) and/or Tax-Expenditure Limitations (TEL). These other fiscal rules or prior experience with a less sophisticated PBB law may increase the likelihood of enacting a state PBB law following GPRA at the federal level. This prior financial prudence path leads to:

H3: Prior fiscal prudence rules increase the state's probability of PBB enactment.

\section{Budget Mimicking}

There is prior research challenging financial and political explanations of the adoption of PBB (Melkers \& Willoughby, 2001). From a sociological point of view, rules are for appropriateness and legitimacy, rather than economic and political rationalities. This explanation is built on March and Olsen's (1996) 'logic of appropriateness', in which right behavior means following rules. Sociological explanations argue that the choice of a rule is a mimetic process to adjust an actor's behavior to its peer, competitor, or neighbor. Even a budgetary rule is adopted as a symbolic response to peer pressure. Isomorphic process of practices (DiMaggio \& Powell, 1983; Pierson, 2000), regional diffusion models in public policy (Berry \& Berry, 1990, 1992; Crain, 1966; Kim et al., 2009), network effects (Ramanna \& Sletten, 2014), and mimicking (Heyndels \& Vuchelen, 1998; Revelli, 2001) view the choice of a rule as a way to follow social norms.

The isomorphic process of practices reflects the sensitivity of actors to the need to legitimate their activities (Pierson, 2000). DiMaggio and Powell (1983) argued that the history of management reforms in governments are full of examples of the isomorphic process of practices. For example, the Planning-Programing-Budgeting System (PPBS) of the McNamara era and the Zero-Based Budgeting (ZBB) of the Carter administration resulted from institutional legitimacy, rather than functional rationality. Likewise, the regional diffusion model of policy argues that there is a relationship between the previous adoption by neighbors and the possibility of current adoption by a government. For example, studies on tax adoption (Berry \& Berry, 1992; Kim et al., 2009) found that the presence of neighboring states that have previously adopted a tax increases the probability of a tax adoption. Even economists use such a sociological factor to explain spatial fiscal interaction among governments. Ramanna and Sletten (2014) found that International Financial Reporting Standard (IFRS) adoption among European countries was self-reinforcing. Revelli (2001) found that when local governments in the United Kingdom decide to change a local property tax rate, they tend to mimic tax rates of neighboring governments. From the budget mimicking hypotheses, a state government may consider other states' budgetary rule choice and follow the dominant choice. From this point of view, PBB can be viewed as a social norm. Therefore, a state may count the number of states adopting PBB within geographical proximity or within the country itself. This behavior leads us to:

H4: Increases in the number of states enacting PBB laws increases the probability of a single state enacting PBB law.

\section{Data and Research Methods}

The goal of this study is to determine what affects a state legislature's decision on whether to enact PBB laws. To test our hypotheses built on four different explanations, a logit model is employed as a discrete event history analysis (EHA). The purpose of EHA is to determine how and what variables influence the probability of an organization's qualitative change (or 'event') 
at a given point in time. In this study, the organizations are states and the event to be analyzed is an enactment of PBB law.

Our data set is a modified panel of 50 states between the years 1993 and 2008. We assume that the social process of vertical learning initiates with GPRA 1993, since the enactment of GPRA at the federal level, should be the moment when the states become 'at risk' of enacting PBB laws. The conceptual dependent variable Enact is the probability that a state will enact the PBB law in a year. Because the nature of enactment is low, Enact is measured with a dummy variable. Enact is coded "O" for the state-year in which PBB law is not enacted and 1 when the law is enacted. Once a state legislature enacts a law related to $\mathrm{PBB}$, the state is dropped from our data set. Therefore, the states that never enacted PBB laws remain in the data set.

To estimate the logit-based discrete time hazard model on the enactment of PBB laws, we use the following EHA model:

Enact $=\beta_{0}+\beta_{1}$ Own Rev. Volatility $+\beta_{2}$ Exp. Volatility $+\beta_{3}$ Fed. Intergovernmental\% $+\beta_{4}$ Non-Tax Rev\% $+\beta_{5}$ Debt Financing Cost $+\beta_{6}$ Ideology $+\beta_{7}$ Governor's Party $+\beta_{8}$ Prior_PBB $+\beta_{9} B B R+\beta_{10}$ TEL $+\beta_{11} U S \_$Wide $+\beta_{12}$ Neighboring States + $\beta_{13}$ Population $+\beta_{14}$ Pop.Growth\% $+\beta_{15}$ Gross State Prod. $+\beta_{16}$ Per Capita Income $+\beta_{17}$ Fed. Unemployment $\%+\beta_{18}$ State Unemployment $\%+\varepsilon$

We choose four different groups of covariates representing the effects of fiscal management, political preference, path dependence, and mimicking. Related to the fiscal management consideration in explaining the motivation of PBB law enactment, we include the following five variables to measure demands for financial management: Own Revenue Volatility, Expenditure Volatility, Fed. Intergovernmental\%, Non-Tax Rev\%, and Debt Financing Cost. The first two measures of financial management are used to recognize financial risk or uncertainty in a state. The term Own Revenue Volatility reflects the level of risk or uncertainty of a state's own source revenue stream. Own Revenue Volatility is measured by a standard deviation of a state's own source revenue in constant dollars per 1,000 people over the period. The term Expenditure Volatility reflects the level of risk or uncertainty of a state's expenditure stream, representing the state's level of demand for public service. Expenditure Volatility is calculated as a standard deviation of the state's expenditures in constant dollar per 1,000 people over the period.

The following three variables measure financial risk and uncertainty due to the financial dependency of a state. Fed. Intergovernmental\% denotes the ratio of intergovernmental transfers (e.g., federal grants) to total revenues. Non-Tax Revenue\% denotes the ratio of nontax revenues (e.g., user fees and charges) to total revenues. Debt Financing Cost is included by calculating the effective interest rate of a state's outstanding debt. Debt Financing Cost is calculated as the total interests paid divided by the total debt outstanding.

To test the political preference explanation, Ideology and Governor's Partisanship are used. Ideology represents the extent to which a state is controlled by a liberal party. This variable is measured by the liberalism score (o through 100) defined by Berry et al. (2010). In their study on state government ideology, the liberalism score is estimated by various variables such as house ideology, senate ideology, and governor's ideology. Since a state's budgetary process is strongly influenced by the executive branch's budget, Governor's Partisanship is included as a proxy for the governor's political preference.

For path-dependency regarding rule choice, we include Prior_PBB, BBR, and TEL.Prior_PBB captures an individual state's prior experience with $\mathrm{PBB}$ laws, which may confound the hazard rate of $\mathrm{PBB}$ enactment after 1993. Prior_PBB is measured with a dummy variable that is coded 1 if a state had a prior PBB law before GPRA and o otherwise. Since there is no temporal 
variation regarding the adoption of $B B R$, we employ the balanced-budget index (1 through 10) estimated by the Advisory Commission on Intergovernmental Relations (ACIR, 1987) and exploit its cross-sectional variation with respect to the stringency of a state's balanced-budget rules. TEL is a dummy variable represented by 1 if a state has a tax and expenditure limitation rule and o otherwise.

To test the mimetic and isomorphic nature of budgetary rule choice, the following two variables are used: US_Wide denotes the total number of states that have adopted PBB laws post-1993; Neighboring States denotes the number of adjacent, border-sharing states that have adopted PBB laws post-1993.

As control variables, the following socioeconomic characteristics of a state are included in the equation: Population denotes population in thousands; Pop. Growth\% denotes the year-overyear population growth rate of a state; Gross State Prod. denotes state gross product in millions of dollars capturing the size of a state's economy; Per Capita Income denotes a state's per capita income in thousands; Fed. Unemployment\% denotes federal unemployment compensation expenditure scaled by federal-level per capita income; and State Unemployment\% denotes state unemployment compensation expenditure scaled by state per capita income. The last three variables represent the state's economic condition. All variable definitions and sources are in the Appendix. In our EHA method, we cluster the error $(\varepsilon)$ on states to address the unobservable state effects.

\section{Results}

We begin our discussion with the descriptive statistics. We observe in Table 2 that Non-Tax Revenue\% indicates that, over the time period, the majority of state revenue came from nontax sources. Debt Financing Costs over our time period, representing the effective interest rate on total debt outstanding, is about $6 \%$. We see that Democrats held about $47 \%$ of the governorships, while the population was leaning liberal on the ideology score over the time period. States leaned toward a very strong balanced budget requirement; $52 \%$ of states adopted rules on tax and expenditure limits, with two bordering states having adopted PBB on average.

The descriptive statistics tell us only part of the legislature's behavior when adopting PBB. One could argue that the four different explanations are simultaneously associated with the practitioners' adoption of PBB. To address the simultaneous choice, we offer Table 3. Here it appears that not all of the different explanations are compatible with the choice of state legislators. In fact, the choice appears to be very strategic. For instance, our results suggest that as Own Revenue Volatility increases, PBB adoption is less likely, while as Expenditure Volatility increases, PBB adoption is much more likely. From a practice point of view, this is understandable. The state's own revenue volatility places the budget in jeopardy due to a lack of own source revenue, not performance, while expenditure volatility indicates a performance issue where spending may not be strategic. While own source revenue is negatively related to PBB adoption, Non-Tax Revenue\% is positively related, although its magnitude is quite weak. We see that Debt Financing Costs are positively related with the odds ratio indicating that as debt financing costs rise, adopting PBB increases by a moderate factor of 1.52 . Within this financial management explanation, Federal Intergovernmental\% is insignificant. Simply put, federal intergovernmental transfers may not significantly affect the state legislators' choice of PBB.

Moving to the next different explanation for $\mathrm{PBB}$, we find that the factors representing political preference are not significant enough to support the influence of politics on state legislators' choice to implement PBB. Looking at the path dependence explanation for PBB adoption, we find that the practitioners' experience with Prior $P B B$ is negatively associated with the odds of 
Table 2. Descriptive Statistics

\begin{tabular}{|c|c|c|c|c|c|}
\hline Variable & $\mathrm{N}$ & Mean & Std. Dev. & Minimum & Maximum \\
\hline PBB Adoption & 412 & 0.09 & $*$ & $\mathrm{O}$ & 1 \\
\hline Own Revenue Volatility & 412 & 0.21 & 0.19 & 0.05 & 2.20 \\
\hline Expenditure Volatility & 412 & 0.22 & 0.10 & 0.09 & 0.77 \\
\hline Federal Intergovernmental\% & 412 & 31.68 & 9.13 & 12.35 & 74.96 \\
\hline Non-Tax Revenue\% & 412 & 57.18 & 7.62 & 34.12 & 87.62 \\
\hline Debt Financing Costs & 412 & 5.65 & 1.15 & 1.32 & 9.99 \\
\hline Ideology & 412 & 52.76 & 21.64 & 6.51 & 92.21 \\
\hline Governor's Party & 412 & 0.47 & $*$ & O & 1 \\
\hline Prior PBB & 412 & 0.22 & $*$ & $\mathrm{O}$ & 1 \\
\hline BBR & 412 & 7.76 & 2.70 & $\mathrm{O}$ & 10 \\
\hline TEL & 412 & 0.52 & $*$ & $\mathrm{O}$ & 1 \\
\hline US_Wide & 412 & $23 \cdot 33$ & 8.46 & 11 & 36 \\
\hline Neighboring States & 412 & 1.86 & 1.45 & $\mathrm{O}$ & 6 \\
\hline Population & 412 & $5,126.70$ & $4,682.59$ & 469 & 31,147 \\
\hline Population Growth\% & 412 & 0.95 & 0.88 & -0.54 & 6.24 \\
\hline Gross State Product & 412 & $182,720.6$ & $197,003.6$ & 13,027 & $1,114,698$ \\
\hline Per Capita Income & 412 & 28.28 & 7.94 & 15.61 & 62.23 \\
\hline Federal Unemployment\% & 412 & 0.40 & 0.14 & 0.22 & 0.62 \\
\hline State Unemployment\% & 412 & 0.39 & 0.23 & 0.06 & 1.44 \\
\hline
\end{tabular}

Note: ${ }^{*}=$ Standard Deviation has limited meaning due to dichotomous variable measure.

PBB adoption. This is an indicator that prior experience matters; however, states' prior experience with PBB has a modest negative effect on PBB adoption. We find the opposite effect of $B B R$. Our results are consistent with the view that practitioners see $B B R$ as a positive effect; as $B B R$ rises, $\mathrm{PBB}$ adoption increases by a modest factor of 1.20. Our findings include that $T E L$ has no statistical impact on PBB adoption.

Our last explanation is budget mimicking. Again, we find that only specific aspects of this different explanation appear to be used by state legislators deciding on PBB adoption. US_Wide, the number of states that have enacted PBB, does influence PBB adoption. As US_Wide increases, adopting PBB increases by a factor of 1.12, a very modest increase. This may indicate that practitioners take US_Wide into consideration, but it is not a large factor in their decision-making. Neighboring States is not a statistically important factor in PBB adoption.

We used a series of control variables found in the previous literature. Our results show that although Population and Gross State Product are statistically significant, they have odds ratios that have extremely small magnitudes. Population Growth\% shows that as Population Growth\% increases, adopting PBB increases by a factor of 1.71. Per Capita Income and State 
Table 3. Event History Model of PBB Enactment

\begin{tabular}{|c|c|c|}
\hline Variable & $\mathrm{z}$ & Odds Ratio \\
\hline \multicolumn{3}{|l|}{ Fiscal Management } \\
\hline Own Revenue Volatility & -1.80 & $0.071^{*}$ \\
\hline Expenditure Volatility & 1.54 & $160.548^{\wedge}$ \\
\hline Federal Intergovernmental\% & -0.66 & 0.980 \\
\hline Non-Tax Revenue\% & 1.82 & $1.049^{*}$ \\
\hline Debt Financing Costs & 1.91 & $1.518^{*}$ \\
\hline \multicolumn{3}{|l|}{ Political Preference } \\
\hline Ideology & 0.71 & 1.011 \\
\hline Governor's Party & -0.55 & 0.675 \\
\hline \multicolumn{3}{|l|}{ Path Dependence } \\
\hline Prior PBB & -1.31 & $0.571^{\wedge}$ \\
\hline BBR & 1.48 & $1.195^{\wedge}$ \\
\hline TEL & 1.02 & 1.521 \\
\hline \multicolumn{3}{|l|}{ Budget Mimicking } \\
\hline US_Wide & 2.10 & $1.121^{*}$ \\
\hline Neighboring States & 0.21 & 1.047 \\
\hline \multicolumn{3}{|l|}{ Controls } \\
\hline Population & 2.42 & $1.000^{*}$ \\
\hline Population Growth\% & 2.53 & $1.707^{*}$ \\
\hline Gross State Product & -1.81 & $1.000^{\wedge}$ \\
\hline Per Capita Income & 0.05 & 1.003 \\
\hline Federal Unemployment\% & 2.38 & $291.713^{*}$ \\
\hline State Unemployment\% & -0.27 & 0.718 \\
\hline Constant & -3.21 & $0.000^{* * *}$ \\
\hline $\mathrm{n}$ & \multicolumn{2}{|c|}{412} \\
\hline Log-Likelihood & \multicolumn{2}{|c|}{$-105 \cdot 40$} \\
\hline LR Chi-squared & \multicolumn{2}{|c|}{41.30} \\
\hline Pseudo R-square & \multicolumn{2}{|c|}{0.1370} \\
\hline
\end{tabular}

Unemployment\% are not statistically important, while Federal Unemployment\% is significant and has a large effect magnitude.

\section{Robustness Checks}

To address the robustness of our results, we offer Table 4 as an examination of the linear combination of the factors that compose the literature's four different explanations. We argue that if the practitioner is choosing based on the underlying factors of the different explanations, we should see a significant result when testing whether or not the linear combination is equal to zero.

We begin with Fiscal Management, which is composed of Own Revenue Volatility + Expenditure Volatility + Federal Intergovernmental\%+ Non-Tax Revenue\% + Debt Financing Costs. As shown in Table 4, we have a very strong odds ratio in magnitude; however, 
Table 4. Robustness Checks of Linear Combinations

\begin{tabular}{lcccc}
\hline \hline & Odds Ratio & Std. Error & $\mathrm{z}$ & $\mathrm{P}>|\mathrm{z}|$ \\
\hline Fiscal Management & 17.79 & 41.47 & 1.23 & 0.217 \\
Political Preference & 0.68 & 0.48 & -0.54 & 0.587 \\
Path Dependence & 1.04 & 0.59 & 0.06 & 0.949 \\
Budget Mimicking & 1.17 & 0.25 & 0.77 & 0.441 \\
\hline
\end{tabular}

the linear combination is statistically insignificant. This result suggests that a unique combination of Fiscal Management factors relevant to each state's fiscal environment needs to be considered to explain PBB adoption. This outcome provides some evidence that practitioners pick certain factors of fiscal management that may not follow the theoretical explanation.

Political Preference, which is composed of Ideology + Governor's Party, appears to have a negative effect on PBB adoption; however, the linear combination is not statistically different than zero as indicated below. This result mimics our findings in our simultaneous analysis.

Next, we look at the explanation called Path Dependence. Path Dependence is composed of Prior $P B B+B B R+T E L$. We note here, similar to our findings in the simultaneous analysis, that the odds ratio indicates a small effect. In addition, the linear combination compels us to state that practitioners are picking their important components that drive PBB adoption, not necessarily those explained in this aspect of the literature.

Lastly, we look at the linear combination of US_Wide + Neighboring States, which make up the Budget Mimicking explanation. As was found in the other linear combinations, we find that the linear combination is no different than a zero effect, with a small odds ratio similar to our simultaneous analysis.

Using these linear combinations, we find that our inference is robust. Our results from our simultaneous analysis lead us to conclude that state legislators chose specific components of what is offered in the academic literature.

\section{Conclusion and Discussion}

We began our research with the goal of explaining why states adopted their own state PBB law at a different time period after the passage of the federal GPRA of 1993. Our study investigates the factors that would lead state legislators to adopt PBB across the nation through four different lenses of motivations: fiscal management demand, political preference, path dependence to the existing fiscal institutions, and budget mimicking hypotheses. We believe that the four explanations are complementary. Four groups of factors influence together, rather than independently or competingly, state legislators in a state to adopt PBB law. State legislators might use strategic aspects of the four different reasons, some of the explanations used sensibly, and some used quite modestly. Where does this leave us? We believe that the literature, as it matures, will conceptually assimilate into the state legislators' behavior. This, of course, assumes that the academic literature can explain behavior, a rather grandiose expectation.

While our empirical result shows that political preferences are not statistically significant factors for states to pass PBB law, state legislators seem to favor the factors associated with the financial management demand to adopt PBB. In addition, the factors of path dependence and mimicking influence states to adopt PBB. 
We hypothesized that a state with prior experience of having old PBB law is likely to reinforce the state to adopt a more sophisticated and rigorous version of PBB law after the federal passage of the GPRA of 1993. However, our empirical result shows that prior experience with PBB has a negative effect on the adoption of a more improved version of PBB. It may imply that the motivation of the state with a type of $\mathrm{PBB}$ to adopt a more rigorous version of $\mathrm{PBB}$ is lower than the motivation of the state without a PBB to adopt a PBB law. It may imply that if a state has already a type of PBB law, the state may tend to keep using the existing version of PBB, instead of replacing it with a new version of it. Meanwhile, if a state has no PBB laws, the state may adopt the most recent version of PBB law. The result may be what exactly path dependency is. In short, the early adopters are less likely.

However, we believe that while this type of path dependency could continue in the short- or medium-term, it will not continue forever. We expect that not only new adopters, but also early adopters, will eventually improve their PBB law. According to Lu and Willoughby's (2018) comprehensive study on the evolution of PBB law, 42 states (84\%) had adopted a PBB law by 2017. In terms of the number of states with a PBB law, the diffusion of PBB law has increased among states over time. In terms of the contents of PBB laws, states have continuously improved their PBB law through amendments toward incorporating more PBB components (Lu \& Willoughby, 2018).

Especially, state governments have confronted fiscal hardship under the COVID-19 pandemic. State governments have spent unusually high levels of public funds to address issues resulting from the COVID-19 pandemic, but they should accommodate break-even budgeting. Therefore, states need innovative budgetary and financial management systems to manage their public funds in order to meet financial challenges, including break-even budgeting. While state governments may have multiple motivations to adopt or improve their PBB laws, our study shows that states tend to adopt PBB laws for fiscal management. The continuously increased number of states adopting PBB, the long-term trend toward improving PBB law, current fiscal challenges, and states' demand for financial management will continue to increase the diffusion of state legislative-driven PBB adoption.

\section{Disclosure Statement}

The author(s) declare that there are no conflicts of interest that relate to the research, authorship, or publication of this article.

\section{References}

Advisory Commission on Intergovernmental Relations. (1987). Fiscal discipline in the federal system: National reform and the experience of the states. https://library.unt.edu/gpo/acir/Reports/policy/a-107.pdf

Aristigueta, M. P., \& Justice, J. B. (2006). The status of performance budgeting. Public Performance \& Management Review, 3o(1), 7-13. http://dx.doi.org/10.2753/PMR1530-9576300100

Berry, F. S., \& Berry, W. D. (1990). State lottery adoptions as policy innovations: An event history analysis. American Political Science Review, 84(2), 395-415. http://dx.doi.org/10.2307/1963526

Berry, F. S., \& Berry, W. D. (1992). Tax innovation in the states: Capitalizing on political opportunity. American Journal of Political Science, 36(3), 715-742. http://dx.doi.org/10.2307/2111588

Berry, W. D., Fording, R. C., Ringquist, E. J., Hanson, R. L., \& Klarner, C. (2010). Measuring citizen and government ideology in the American states: A re-appraisal. State Politics 
and Policy Quarterly, 10(2), 117-135.

http://dx.doi.org/10.1177/153244001001000201

Bourdeaux, C. (2006). Do legislatures matter in budgetary reform? Public Budgeting and Finance, 26(1), 120-142. http://dx.doi.org/10.1111/j.1540-5850.2006.00841.x

Broom, C. A. (1995). Performance-based government model: Building a track record. Public Budgeting and Finance, 15(4), 3-17. http://dx.doi.org/10.1111/1540-5850.01050

Breul, J. D. (2007). GPRA: A foundation for performance budgeting. Public Performance \& Management Review, 3o(3), 312-331. http://dx.doi.org/10.2753/PMR15309576300301

Cameron, D. (1978). The expansion of the public economy: A comprehensive analysis. American Political Science Review, 72(4), 1243-1261. http://dx.doi.org/10.2307/1954537

Crain, R. L. (1966). Fluoridation: The diffusion of innovation among cities. Social Forces, 44(4), 467-476. http://dx.doi.org/10.2307/2575080

Crain, W. M. (2003). Volatile states. University of Michigan Press. http://dx.doi.org/10.3998/mpub.16580

Crain, W. M., \& O’Roark, J. B. (2004). The impact of performance-based budgeting on state fiscal performance. Economics of Governance, 5(2), 167-186. http://dx.doi.org/10.1007/s10101-003-0062-6

Davis, O. A., Dempster, M. A. H., \& Wildavsky, A. (1974). Toward a predictive theory of government expenditure. British Journal of Political Science, 4(4), 419-452. https://doi.org/10.1017/Soo07123400009650

DiMaggio, P. J., \& Powell, W. W. (1983). The iron cage revisited: institutional isomorphism and collective rationality in organizational field. American Sociological Review, 48(2), 147-160. http://dx.doi.org/10.2307/2095101

Florida Auditor General. (2007). Local government entity financial condition assessment procedure. https://flauditor.gov/pages/fca procedures.html

Friedman, L. C. (1975). Control, management and planning: an empirical examination. Public Administration Review, 35(6), 625-628. http://dx.doi.org/10.2307/974282

Government Accountability Office. (1997). Performance budgeting: Past initiatives offer insights for the Government Performance and Results Act (GPRA) implementation (GAO/AIMD-97-46).

Grizzle, G. A., \& Pettijohn, C. D. (2002). Implementing performance-based program budgeting: A system-dynamics perspective. Public Administration Review, 62(1), 5162. http://dx.doi.org/10.1111/1540-6210.00154

Heyndels, B., \& Vuchelen, J. (1998). Tax mimicking among Belgian municipalities. National Tax Journal, 51(1), 89-101. https://www.journals.uchicago.edu/doi/abs/10.1086/NTJ41789314

Hou, Y., Lunsford, R. S., Sides, K. C., \& Jones, K. A. (2011). State performance-based budgeting in boom and bust years: An analytical framework and survey of the states. Public Administration Review, 71(3), 370-388. http://dx.doi.org/10.1111/j.15406210.2011.02357.X

Jones, L. R., \& McCaffery, J. L. (2010). Performance budgeting in the U.S. federal government: History, status, and future implications. Public Finance and Management, 1O(3), 482-523. http://pfm.spaef.org/articles

Joyce, P. G. (1993a). The reiterative nature of budget reform: Is there anything new in federal budgeting? Public Budgeting and Finance, 13(3), 36-48. http://dx.doi.org/10.1111/1540-5850.00981

Joyce, P. G. (1993b). Using performance measures for federal budgeting: Proposals and prospects. Public Budgeting and Finance, 13(4), 3-17. http://dx.doi.org/10.1111/1540-5850.00987

Joyce, P. G. (1997). Using performance measurement for budgeting: A new beat or is it the same old tune? In K. Newcomer (Ed.), Using performance measures for public and nonprofit programs, (pp. 45-61). Jossey-Bass. 
Kiewiet, D. R., \& McCubbins, M. D. (1985). Congressional appropriation and the electoral connection. Journal of Politics, 47(1), 59-82. http://dx.doi.org/10.2307/2131066

Kim, D. J., Bae, S. S., \& Eger, R. J., III. (2009). Is local discretionary sales tax adopted to counteract fiscal stress? Economic Development Quarterly, 23(2), 150-166. http://dx.doi.org/10.1177/0891242408327708

Klase, K. A. \& Dougherty, M. J. (2008). The impact of performance budgeting on state budget outcomes. Journal of Public Budgeting, Accounting, \& Financial Management, 2O(3), 277-298. http://dx.doi.org/10.1108/JPBAFM-20-03-2008Boo1

Lee, J. Y., \& Wang, X. H. (2009). Assessing the impact of performance-based budgeting: A comparative analysis across the United States, Taiwan, and China. Public Administration Review, 69(S1), S60-S66. http://dx.doi.org/10.1111/j.15406210.2009.02090.x

Lee, R. D. (1997). A quarter century of state budgeting practices. Public Administration Review, 57(2), 133-140. http://dx.doi.org/10.2307/977061

Lu, Y., \& Willoughby, K. (2018). Public Performance Budgeting Principles and Practice. Routledge. https://doi.org/10.4324/9781315525730

Lu, Y., Willoughby, K., \& Arnett, S. (2009). Legislating results: Examining the legal foundations of PBB systems in the states. Public Performance \& Management Review, 33(2), 266-287. http://dx.doi.org/10.2753/PMR1530-95763330206

Lu, Y., Willoughby, K., \& Arnett, S. (2011). Performance budgeting in the American states: What's law got to do with it? State and Local Government Review, 43(2), 79-94. http://dx.doi.org/10.1177/0160323X11407523

March, J. G., \& Olsen, J. P. (1996). Institutional perspective on political institutions. Governance, 9(3), 247-264. http://dx.doi.org/10.1111/j.1468-0491.1996.tbo0242.x

Melkers, J., \& Willoughby, K. (1998). The state of the states: Performance-based budgeting requirements in 47 out of 50. Public Administration Review, 58(1), 66-73. http://dx.doi.org/10.2307/976891

Melkers, J., \& Willoughby, K. (2001). Budgeters' views of state performance-budgeting systems: Distinctions across branches. Public Administration Review, 61(1), 54-64. http://dx.doi.org/10.1111/0033-3352.00005

Mitnick, B. M. (1975). The theory of agency: The policing "paradox" and regulatory behavior. Public Choice, 24(1), 27-42. http://dx.doi.org/10.1007/BF01718413

Moynihan, D. P. (2006). Managing for results in state government: Evaluating a decade of reform. Public Administration Review, 66(1), 77-89. http://dx.doi.org/10.1111/j.1540-6210.2006.005.57.x

Niskanen, W. A., Jr. (1968). The peculiar economics of bureaucracy. American Economic Review, 58(2), 293-305. https://www.jstor.org/stable/1831817

Niskanen, W. A., Jr. (1971). Bureaucracy and representative government. Aldine. http://dx.doi.org/10.4324/9781315081878

Pierson, P. (2000). Increasing returns, path dependence, and the study of politics. American Political Science Review, 94(2), 251-267. http://dx.doi.org/10.2307/2586011

Qi, Y., \& Mensah, Y. M. (2012). An empirical analysis of the effects of performance-based budgeting on state government expenditures. SSRN. https://dx.doi.org/10.2139/ssrn.1970079

Ramanna, K., \& Sletten, E. (2014). Network effects in countries' adoption of IFRS. Accounting Review, 89(4), 1517-1543. http://dx.doi.org/10.2308/accr-50717

Revelli, F. (2001). Spatial patterns in local taxation: Tax mimicking or error mimicking? Applied Economics, 33(9), 1101-1107. http://dx.doi.org/10.1080/00036840010007164

Rubin, I. S. (1990). Budget theory and budget practice: How good the fit? Public Administration Review, 5O(2), 179-189. http://dx.doi.org/10.2307/976865

Schick, A. (1966). The road to PPB: The stages of reform. Public Administration Review, 26(4), 243-258. https://doi.org/10.2307/973296

Schick, A. (1971). Budget innovations in the states. Brookings Institution. 
Smith, R. W., \& Bertozzi, M. (1998). Principals and agents: An explanatory model for public budgeting. Journal of Public Budgeting, Accounting, \& Financial Management, 1O(3), 325-353. http://dx.doi.org/10.1108/JPBAFM-10-03-1998-Bo01

Spencer, B. (1980). Outside information and the degree of monopoly power of a public bureau. Southern Economic Journal, 47(1), 228-233. http://dx.doi.org/10.2307/1057076

Spencer, B. (1982). Asymmetric information and excessive budgets in government bureaucracies: A principal and agency approach. Journal of Economic Behavior and 3(2-3), 197-224. https://www.sciencedirect.com/science/article/abs/pii/o16726818290018X

Staley, T. (2015). The effect of TELs on state revenue volatility: Evidence from the American states. Public Budgeting and Finance, 35(1), 29-48. http://dx.doi.org/10.1111/pbaf.12054

Staley, T. (2017). The impact of fiscal limits on state revenue volatility. American Review of Public Administration, 47(4), 443-454. https://doi.org/10.1177\%2F0275074015589341

Stanford, K. A. (1992). State budget deliberations: Do legislators have a strategy? Public Administration Review, 52(1), 16-26. http://dx.doi.org/10.2307/976542

Thompson, F. (1994). Mission-driven, results-oriented budgeting: Fiscal administration and the new public management. Public Budgeting and Finance, 14(3), 90-105. http://dx.doi.org/10.1111/1540-5850.01014

Tufte, E. R. (1978). Political control of the economy. Princeton University Press.

Wildavsky, A. (1961). Political implications of budget reform. Public Administration Review, 21(4), 183-190. http://dx.doi.org/10.2307/973628

Wildavsky, A. (1988). Ubiquitous anomie: Public service in an era of ideological dissensus. Public Administration Review, 48(4), 753-755. http://dx.doi.org/10.2307/975598

Willoughby, K., \& Benson, P. (2011). Program evaluation, performance budgeting and Program Assessment Rating Tool (PART): The U.S. federal government experience [Working paper]. International Studies Program, Georgia State University.

\section{Author Biographies}

Sungkyu Jang is an Assistant Professor of Public Administration in the Department of Political Science at Indiana University South Bend. His research interests are tax collection, performance budgeting, and accounting for governmental and nonprofit entities. He has been published in the American Review of Public Administration.

Sung-Jin Park is an Assistant Professor in Accounting at Indiana University South Bend (IUSB). Prior to joining IUSB, he taught at the University of Texas at San Antonio and practiced public accounting in the state of Indiana. Dr. Park is a Certified Public Accountant and a member of the American Accounting Association.

Robert J. Eger III is the Neven C. Hulsey Endowed Chair in Business Excellence and Professor of Accounting at the Eberhardt School of Business, University of the Pacific. His areas of interest are governmental and nonprofit accounting, public financial management, and methodology. He has published in an array of academic and practice journals on topics that include accounting in government, defense auditing and spending, public health financing, tax strategies and complexities, tax evasion and auditing activity, and managing intergovernmental revenues. 


\section{Appendix}

Table A1. Variable Definitions

\begin{tabular}{|c|c|}
\hline Variable Name & Definition \\
\hline \multicolumn{2}{|l|}{ Dependent Variable } \\
\hline Enactment & $\begin{array}{l}\text { An indicator variable equals " } 1 \text { " when a state } \\
\text { enacts PBB laws and "o" otherwise (Lu et al., } \\
\text { 2009) }\end{array}$ \\
\hline \multicolumn{2}{|c|}{ Consideration of Fiscal Management } \\
\hline Own Revenue Volatility & $\begin{array}{l}\text { Standard deviation of state's own revenue in } \\
\text { constant dollar per 1,ooo people over 12-year } \\
\text { periods (U.S. Census Bureau) }\end{array}$ \\
\hline Expenditure Volatility & $\begin{array}{l}\text { Standard deviation of state's expenditure in } \\
\text { constant dollar per 1,ooo people over 12-year } \\
\text { periods (U.S. Census Bureau) }\end{array}$ \\
\hline Debt Financing Costs & $\begin{array}{l}\text { A state's effective interest rate on the debts } \\
\text { outstanding calculated as the total interests paid } \\
\text { divided by the total debt outstanding (U.S. Census } \\
\text { Bureau) }\end{array}$ \\
\hline Fed. Intergovernmental\% & $\begin{array}{l}\text { The ratio of intergovernmental transfer from the } \\
\text { federal government to a state's total revenue (U.S. } \\
\text { Census Bureau) }\end{array}$ \\
\hline Non-Tax Revenue\% & $\begin{array}{l}\text { The ratio of a state's non-tax revenue to total } \\
\text { revenue (U.S. Census Bureau) }\end{array}$ \\
\hline \multicolumn{2}{|l|}{ Political Preference } \\
\hline Ideology & $\begin{array}{l}\text { State Government Ideology Index (i.e., liberalism } \\
\text { score; Berry et al., 2010) }\end{array}$ \\
\hline Governor's Party & $\begin{array}{l}\text { An indicator variable equals " } 1 \text { " when a governor is } \\
\text { a member of the Democratic Party and "o" } \\
\text { otherwise }\end{array}$ \\
\hline
\end{tabular}

An indicator variable equals " 1 " when a state has

Prior_PBB PBB laws before 1993 and "o" otherwise (Lu et al., 2009)

BBR

Balanced-Budget Index: “ 1 ” indicating a very weak balanced-budget requirement through " 10 " a very strong balanced-budget requirement (ACIR, 1987) An indicator variable equals " 1 " when a state

TEL adopts the rules on tax and expenditure limitations and "o" otherwise (Staley, 2015)

\section{Budget Mimicking}

US_Wide

Neighboring States

Control Variables

Population

Pop. Growth\%

The number of states that enacted PBB laws The number of border-sharing states that enacted PBB laws

The population of a state in thousands (U.S. Bureau of Economic Analysis)

A state's annual population growth rate (U.S. Bureau of Economic Analysis) 
Gross State Prod.

Per Capita Income

Federal Unemployment\%

State Unemployment\%
A state's gross domestic production in millions of dollars (U.S. Bureau of Economic Analysis)

A state's per capita income in thousands of dollars (U.S. Bureau of Economic Analysis)

The ratio of federal unemployment benefit expenditure to the per capita income at the federal level (U.S. Bureau of Economic Analysis; U.S.

Census Bureau)

The ratio of state unemployment benefit expenditure to the per capita income of the state (U.S. Bureau of Economic Analysis; U.S. Census Bureau) 